\title{
Семенов С.Г.
}

Навруз, Нарӑс - праздник пробуждения природы и начало новой жизни

Общественное объединение «Сувар»

(Россия, Чебоксары)

doi: 10.18411/lj-01-2019-55

idsp: ljournal-01-2019-55

\section{Аннотация}

В статье описывается «Навруз, Нарӑс», как международный праздник. Что готовится к празднику и какие блюда украшают в этот день праздничный стол. Также как народный праздник достиг международного статуса.

Ключевые слова: праздник «Навруз, Нарӑс», пробуждение, проросшая пшеница, весеннее солнцестояние, традиционные блюда.

\section{Abstract}

The article describes Navruz, Narăs, as an international holiday. What is preparing for the holiday and what dishes decorate the holiday table on this day. Just as the national holiday has reached international status.

Keywords: Navruz, Narăs holiday, awakening, sprouted wheat, spring solstice, traditional dishes.

Актуальность исследуемой проблемы обусловлено тем, что в последнее время древнейший праздник Навруз (Нарӑс - по суваро-чувашски) завоевывает все большую популярность. Навруз (имеются другие варианты: Ноуруз, Невруз; дословный перевод означает «новый день») - или праздник Нового года, корни которого надо искать в глубине тысячелетий. Он опирается на древние земледельческие традиции и является символом возрождения жизни. Праздник «Навруз-Нарӑс» отмечается в дни весеннего равноденствия или начала нового солнцестояния по солнечному календарю, в пору пробуждения природы от зимнего сна и вхождения солнца в созвездие Овна, тем самым подтверждая его планетарность. Иначе говоря, это взаимосвязь космоса и земли предвещает новый импульс, обновление, пробуждение природы и всего живого на земле, включая и человека $[1 ; 6 ; 7]$.

Необычно ценной чертой этого праздника является то, что, не взирая ни на что, он выстоял, и настолько глубоко сплотился с душевными чувствами народов этой земли, что они с большим трепетом ждут его ежегодного наступления и готовы его встретить достойно.

Солнце является значимым атрибутом в нашей жизни, небесные светила, созвездия и звезды на этот день после годового круговорота прибывают на свои точки первоначального пребывания и принимаются к движению по новому кругу. День, когда уравниваются день и ночь по солнечному календарю, принято считать началом Нового года. Существует мнение, что в этот день происходит пробуждение природы, которая на землю спускает добро и благодать, изгоняет злые духи, которые не проникнут в обитель людей. Поэтому «Навруз-Нарӑс» считается светлым и веселым праздником.

В традиции празднования «Навруз-Нарӑс» заложены нравственные качества людей, обладающие открытостью, сердечностью, отзывчивостью, милосердием. Это тоже имеет немаловажное значение и причиной того, что его наступление ждут с нетерпением. C Навруз-Нарӑсом начинаются подготовительные работы нового земледельческого года в крестьянской среде, поэтому он имеет важное прикладное значение, т.к. отмечается момент перехода к земельному труду, новому земледельческому циклу $[1 ; 4 ; 5 ; 6]$.

Этот момент имел большое значение, как для благополучия общины, так и для понимания и мироощущения землепашца, поскольку земледелец мыслил рамками земледельческого цикла, основным принципом которого выступал день сева. Благодаря 
этому, с Навруз-Нарӑсом начинались не только подготовка к посевным работам, но и целая стадия жизнедеятельности людей.

Праздник Навруз не относится к конкретной религии или конфессии, а акцентирует обновление, зарождение природы. Он как народный праздник, существует испокон веков, органично внедрился в культурную жизнь многих народов и регионов мира.

Отличительная черта Навруз-Нарӑса - его светский характер в отличие от большинства торжеств в исламском и христианском мире.

С сентября 2009 г. Навруз числится в репрезентативном списке нематериального культурного наследия человечества ЮНЕСКО, а с конца февраля 2010 г. 64-я сессией Генеральной Ассамблеи ООН было объявлено 21 марта, как «Международный день Навруза». Эта дата празднования - 21 марта, избрана неслучайно, потому что она приходится на весеннее равноденствие, когда продолжительность дня равняется с продолжительностью ночи, и весна решительно входит в свои права. Тем самым Навруз и мусульманский Новый год отличаются друг от друга, потому что основой мусульманского календаря является лунный годичный цикл [8].

Так как один год солнечного календаря содержит 365 (366) дней, а лунного - 354 (355) дней, в связи с чем, лунный год со всеми своими датами относительно солнечного передвигаются приблизительно на одиннадцать дней вперед.

Мы вправе думать день весеннего равноденствия, как «официальное» начало весны в северном полушарии. К примеру, в 2017 году весеннее равноденствие наступило 20 марта в 10.29 по Гринвичу (13.29 мск). В то самое время центр Солнца пересекает небесный экватор и покидает южное полушарие Земли в сторону северного. С данной минуты до самого летнего солнцестояния ночи становятся короче дней.

Праздник «Навруз-Нарӑс» является самым древним на Земле, так как его праздновали еще до зороастрийские времена, т.е. до VII в. до н.э. «Навруз-Нарӑс» посвящались много теплых строк древнегреческим географом и историком - Страбоном (64-63 до н.э. - ок. 23-24 н.э.). В своих записях он представляет, какой смысл праздник имел в те времена, как народ почитал этот праздник. «В самые древние, давние времена и по сегодняшние жители Междуречья собираются в этот день в Храме огня. Это самый почитаемый праздник, когда торговцы закрывают свои лавки, ремесленники прекращают работу, все веселятся, угощают друг друга теми напитками и кушаньями, которых коснулся огонь» [7]. Также этот праздник восхвалялся в своих стихах поэтом Фирдоуси (935-1020 гг.), философом, поэтом, математиком, астрономом и астрологом Омаром Хайямом (1048-1131 гг.) [8].

Принято считать, что по происхождению праздник «Навруз-Нарӑс» относится древнеиранскому легендарному пророку Заратуштры, связанному с культом Солнца. Возможно, именно от зороастризма «Нарӑс» приобрел обряд почитания предков. В этот день обязательно нужно навестить родных и близких с угощением и попросить прощения [1].

До начала праздника проводилась тщательная уборка жилья, обновлялась домашняя утварь и одежда, украшались жилища, убиралась территория вокруг обиталищ от мусора, приводились улицы в совершенный порядок от зимней грязи. К празднику все надевали новую одежду, покаялись, примирялись с недругами, простили долги.

Даже на современном этапе, приходу Навруз-Нарӑс, т.е. Новому году готовятся и проводят предварительный символический обряд очищения. Последняя среда недели перед наступлением Навруз-Нарӑс - особенная, которая называется «средой радости», так как в этот день все улицы городов и сел светятся от зажженных костров. Поэтому в этот день все люди, от стариков до малых детей семь раз должны перескочить через один и тот же костер, или же перепрыгнуть последовательно через семь костров. Последнюю ночь проходящего года провожают особенно весело, обрызгивая друг друга чистой водой и 
перепрыгивая через чистый ручеек с тем, чтобы очистить свое тело и дух от накопившихся прошлогодних грехов.

Навруз-Нарӑс - это что-то больше, нежели просто праздник. Традиционные блюда древнего и красивого праздника очень разумны, полноценны углеводами, белками и жирами. Главным украшением праздничного стола является проросшая пшеница. Нашим предкам в течение тысячелетий после продолжительной зимы приходилось бороться с недостатком витаминов в организме, с помощью элементарного, но весьма результативного средства - проросшей пшеницы. Благодаря современной науке можно доказать, что пятьдесят граммов ростков пшеницы содержат столько же витаминов «С», сколько содержит шесть стаканов апельсинового сока.

В составе пророщенной пшеницы содержатся почти вся группа витаминов «В» и продукт богат минералами, такими как: калий и железо, цинк, кальций, фосфор, селен, магний, натрий, медь и марганец.

В этот день ритуальным блюдом из проросшей пшеницы в течение многих тысячелетий украшались праздничные весенние столы, с которыми связаны многочисленные предания, легенды, верования и традиции.

В течение двух недель до начала праздника начинается проращивание зерен пшеницы. Зерна пшеницы до праздника должны иметь зеленые всходы до семи сантиметров и украшать праздничный стол и являются главным символом и украшением стола, также рождением новой жизни - Нового года. Это начало приготовления, но на этом подготовка не заканчивается, перед самым праздником зерна проращиваются снова, как основа праздничного стола. Всем гостям предлагается блюдо с едва взошедшими зернами, как символа приобщения к возрождению всего живого. В этот день накрывается стол не только проросшей пшеницей, но и разными сладкими блюдами.

Ритуал «Навруз-Нарӑс» - это не только сладкий стол и обильное застолье, но он сопровождается еще и детскими песнями про праздник. Детей щедро одаривают разными сладостями в каждом доме, куда они приходят петь песни про Новый год. Все улицы наполнены в эти дни песнями, танцами, шутками.

В древности «Навруз-Нарӑс» праздновался ровно тринадцать дней. По окончании торжеств народ выходил в поле, где и встречал Новый год. Такая существовала примета. Считалось, что человек вышедший в праздничные дни в поле испытать наслаждение природой, в течение всего будущего года будет испытывать удачу и достаток.

Праздник «Навруз-Нарӑс» не имеет к исламской, христианской, буддистской религии никакого отношения.

Мӑнкун (на современный суваро-чувашский язык переводится как «Великий день, возжжение огня Нового года). Нарӑс, Мӑнкун - один из самых главных праздников наших предков, и этот день праздник справляли у родственников по мужской линии с 21 марта по 1 апреля [1].

Возвращаясь к историческим корням данного праздника, можно найти в нем много схожего со славянским праздником Масленица. Масленица - это также древний славянский праздник, также пришедший из древней культуры и сохранившийся после принятия христианства. И по времени Масленица совпадает с празднованием «НаврузНарӑс». По своей жанровой составной Масленица - это та же, как и Навруз, самый веселый и сытный народный праздник, который продолжается целую неделю [3].

Появлению «Нового солнца» символизирует румяный и горячий блин, но со временем возник новый календарь, и со смещением чисел в нём - праздник переместился на иную дату, и до сегодняшнего дня дошёл как «проводы зимы» на Масленицу.

Среди обычаев празднование Масленицы также включает в себя прыжки через костер, изгнание злых духов, праздничные представления, народные гуляния. Также, как и «Навруз-Нарӑс» Масленица на протяжении многих веков сохраняла характер народного гулянья. 
Подобно «Навруз-Нарӑсу» существует праздник «Масленица» символизирует проводы зимних холодов и встречу весны. В «Масленицу», как и в преддверии «НаврузНарӑса», сжигается деревянное чучело, тем самым объявляется всем о приходе тепла, придающего человеку новую жизненную энергию. Каждый из семи дней народных гуляний отмечается массовыми играми, катаниями на санках, разведением костров и прочими забавами, а также выпечкой традиционных для этого праздника блинов. Особое место в дни «Масленицы», как и в «Навруз-Нарӑсе», отводится посещению молодыми супругами родителей, старших по возрасту родственников, помощи неимущим, молитвам $[1 ; 3 ; 5]$.

Есть много разных традиций подготовки и празднования этого большого праздника, которые дошли до нас от наших прародителей из глубины веков.

«Навруз-Нарӑс» - праздник обновления и слияния с природой. С точки зрения эзотерики, основные действия Навруз-Нарӑса направлены на приобретение благоприятных энергий возрождения и света. Как результат вобравший в себя культурные традиции нескольких цивилизаций, он считается древнейшим доисламским и дохристианским праздником. Его воспевают на родном языке многие народы, что является значимым вектором в идейно-эстетическом воспитании молодого поколения, которое способствует формированию национального самосознания подрастающего поколения и расширяет их мировоззрение

Следует отметить, что «Навруз-Нарӑс» появился и празднуется с незапамятных времен, когда современные религии и национальности еще не существовали. Множество праздников у разных народов имеют родственные корни, только именуются они поразному и имеют некоторые отличия. За многие сотни лет праздник «Навруз-Нарӑс» не исчез, сменив разных правителей и завоевателей на своем пути. Он просто выжил за счет широкой социальной основы при различных верованиях и государствах, а также приобрел значимый государственный смысл. В США 21 марта отмечается как День сельского хозяйства. У иранцев, для которых Навруз является действительно народным праздником, бытует два Навруза. Это: Малый и Большой Науруз. Малый Науруз - начало весны. Большой Навруз - шестой день месяца Фарфардин [2; 4; 5; 6].

В заключение необходимо отметить то, что в Российской Федерации уже существует традиция ежегодно отмечать «Навруз» на официальном уровне. Так, при поддержке московской мэрии и содействии российского Союза соотечественников проводятся мероприятия, связанные с празднованием этой даты. К примеру, 21 марта ежегодно в концертном зале «Россия» московского спортивного комплекса «Лужники» собираются различные творческие коллективы из разных стран ближнего зарубежья и регионов России. Организуются выставки, в том числе и кулинарные, с демонстрацией самобытной народной кухни, ярмарки продаж национальных поделок, а также специальные детские программы. Подобные мероприятия проводятся в таких российских городах, как Воронеж, Чебоксары, Ростов-на-Дону, Краснодар, Калуга, Кострома, Казань, Новосибирск, Ярославль, Тула, Владимир, Муром, Химки, Тамбов, Калининград, и другие. В последние годы возрос интерес к древнему празднику «Навруз-Нарӑс» и среди самого русского народа. Они воспринимает его как предвестник грядущей весны и пробуждение природы. Из этого следует, что в перспективе это яркий, веселый и «сладкий праздник» охватит многие страны и континенты, потому что он вне религии и вне национальности и имеет светский характер.

$$
* * *
$$

1. Алмантай, В.Н. Культурная идентичность суваро-чувашей в условиях глобализации / В.Н. Алмантай. Чебоксары: Чуваш. кн. изд-во, 2018. - 167 с.

2. Айни, С. Гулянье в Файзабаде. - Соч. - Т. 4. - М., 1974.

3. Лыкошин, Н. Встреча весны - Сайл в Худжанде/Туркестанские ведомости, от 16.03.1903. - № 22.

4. Негмати, А.Э. Земледельческие календарные праздники древних таджиков и их предков. - Душанбе, 1989. 
5. Раджабов, 3.Ш. Страницы прошлого. - Душанбе, 1986.

6. Рык-Богданик. Навруз в Ходженте//Туркестанские ведомости. - 12.03.1906, - № 40.

7. Страбон. География. - М.: «Наука», 1964.

8. http://www.ferghana.ru/article.php?id=5639; http://www.uztour.biz/navruz.htm; http://www.navruz.edunet.uz/; http://www.lawfulstate.ru/civboomreligissl.html; http://www.navruz.edunet.uz/gip.htm 